\title{
Primary plasmacytoma of the thyroid gland: a case report of a rare neoplasia
}

\author{
Plasmocitoma da glândula tireoide: relato de caso de uma rara neoplasia
}

Eduardo Cambruzzi'; Alberto Salgueiro Molinari²; Diego Mendonça Uchôa ${ }^{3}$; Vanessa Yépez ${ }^{4}$

\begin{tabular}{l|l}
\multicolumn{1}{c|}{ key words } & abstract \\
\hline Plasmacytoma & $\begin{array}{l}\text { Extramedullary plasmacytoma comprises 3\%-5\% of all plasma cell neoplasms, and approximately } 80 \% \\
\text { of the cases occur in the upper respiratory tract. Primary thyroid plasmacytomas (PTP) are rare tumors. } \\
\text { Thyroid gland }\end{array}$ \\
$\begin{array}{l}\text { The authors report a case of PTP in a male patient with dyspnea and dysphagia. Physical examination } \\
\text { and computerized tomography (CT) scan revealed a solid tumor affecting the thyroid gland, measuring } \\
\text { Immunohistochemistry }\end{array}$ & $\begin{array}{l}12 \mathrm{~cm} \text { in its greatest dimension. Surgical biopsy was performed. Microscopy revealed a hypercellular } \\
\text { malignant neoplasm composed of round plasmacytoid cells arranged in solid nests, which showed a } \\
\text { positive immunoexpression for CD138, epithelial membrane antigen (AME), kappa light chains and } \\
\text { multiple myeloma oncogene 1 (MUM1). The diagnosis of PTP was accordingly established. }\end{array}$
\end{tabular}

resumo

O plasmocitoma extramedular constitui 3\%-5\% de todas as neoplasias de plasmócitos e aproximadamente $80 \%$ dos casos ocorrem no trato respiratório superior. Plasmocitomas primários da tireoide (TPP) são tumores raros. Os autores relatam um caso de TPP em um paciente masculino referindo dispneia e disfagia. O exame físico e a tomografia computadorizada revelaram tumor sólido comprometendo a glândula tireoide, medindo $12 \mathrm{~cm}$ na maior dimensão, o qual foi submetido à biópsia cirúrgica. À microscopia, foi identificada neoplasia maligna hipercelular constituída por células redondas/plasmocitoides dispostas em ninhos sólidos, as quais exibiam imunoexpressão positiva para CD138, antígeno da membrana epitelial (AME), cadeias leves kappa e oncogene mieloma múltiplo 1 (MUM1). O diagnóstico de TPP foi, então, estabelecido.
Primeira submissão em 29/12/11 Última submissão em 05/03/12 Aceito para publicação em 23/03/12 Publicado em 20/08/12 unitermos

Plasmocitoma

Glândula tireoide

Mieloma múltiplo

Imuno-histoquímica

1. Pós-doutor em Patologia Cardiovascular pelo Instituto de Cardiologia do Rio Grande do Sul; professor da Universidade Luterana do Brasil (Ulbra); patologista.

2. Mestre em Cirurgia Endócrina.

3. Especialista em Patologia; pesquisador da Universidade Federal do Rio Grande do Sul (UFRCS).

4. Residente em Endocrinologia do Hospital Nossa Senhora da Conceição-Porto Alegre. 


\section{Introduction}

The majority of thyroid neoplasms are primary and shows epithelial differentiation. Papillary carcinoma of the thyroid is the most common malignant tumor in the gland in countries having iodine-sufficient or iodine-excess diets, affecting more frequently women between the third and fifth decades. Primary lymphoid tumors arising in the thyroid are seen more commonly on elderly females, being diffuse large B-cell lymphoma the most common histological type $\mathrm{e}^{(1,7,12)}$

Plasma cell myeloma is more frequently seen as a bone marrow-based, multifocal neoplasm characterized by a serum monoclonal protein, skeletal osteolytic lesions, pathological fractures, bone pain, hypercalcemia, and anaemia. Extraosseous (extramedullary) plasmacytomas constitute $3 \%-5 \%$ of all plasma cell neoplasms. Patients are typically adults (median age 55) with a 2:1 male:female ratio, and approximately $80 \%$ of these lesions occur in the upper respiratory tract. Plasmacytoma affecting the thyroid parenchyma are more commonly seen as a component of widespread myeloma, presenting as a palpable nodule in about $2.6 \%$ in this group of patients. Thyroid primary plasmacytoma is a very rare neoplasm $^{(3,6,9,11)}$.

Herein, the authors report a case of primary thyroid plasmacytoma with no clinical evidence of systemic disease, and review clinical features, pathological findings and diagnostic criteria of this tumor.

\section{Case report}

Male patient, 56 years, caucasian, came to the ambulatorial service reporting dyspnea and dysphagia beginning three months. He also reported the presence of a nodular lesion in the cervical region with progressive growth. Physical examination showed the presence of a solid tumor with indistinct borders in the anterior cervical region, associated with enlarged lymph nodes. The patient had a history of hypothyroidism with levothyroxine use. The computed tomography (CT) scan revealed the presence of a neoplastic process affecting predominantly the isthmus and right lobe of the thyroid gland, which measured $12 \mathrm{~cm}$ in greatest dimension and determined deviation of the trachea to the left. At fibrobroncoscopic examination, an accentuated stenosis of the tracheal lumen by an extrinsic process was found, without involvement of the mucosa. The neoplastic process and the cervical lymph nodes underwent fine needle aspiration. The Pap test identified the presence of some atypical polyhedral cells consistent with hematopoietic malignancy in the thyroid smears, and numerous lymphocytes in a hyperplastic pattern in the lymph nodes smears. Because of progressive dyspnea, the patient underwent tracheostomy and biopsy of the lesion. At microscopic, a hypercellular malignant neoplasm constituted by round or plasmacytoid cells arranged in solid nests and/or in a diffuse pattern was found (Figure 1), which exhibited high mitotic index (Figure 2) and with foci of necrosis too. The immunohistochemistry of the lesion showed positive expression for the antibodies CD138 (Figure 3), epithelial membrane antigen (EMA), kappa light chains of immunoglobulins (Figure 4), MUM1 and CD56 (weak and focal) and negative expression for CD20 antibody, lambda light chains of immunoglobulins and pancytokeratin (AE1/AE3). The laboratory data are described in Table. Conventional radiological study and the scintigraphy of the skull, chest, spine and upper and lower limb did not identified any lytic or blastic bone lesion. The diagnosis of plasmacytoma of the thyroid gland was then established. Although the specific treatment regimen established, which included radiation therapy, patient past way from respiratory failure.

\section{Discussion}

Multiple myeloma is a tumor of hematopoietic derivation, and it is the most common primary malignant

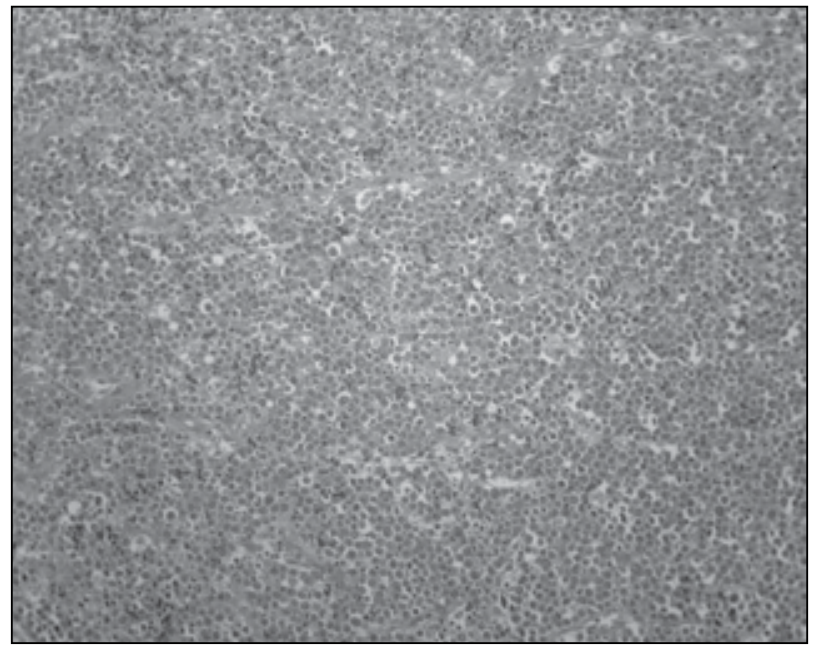

Figure 1 - Thyroid plasmacytoma: aneoplastic malignant lesion constituted by round plasmacytoid cells, HE, 40x $H E$ : hematoxylin and eosin. 


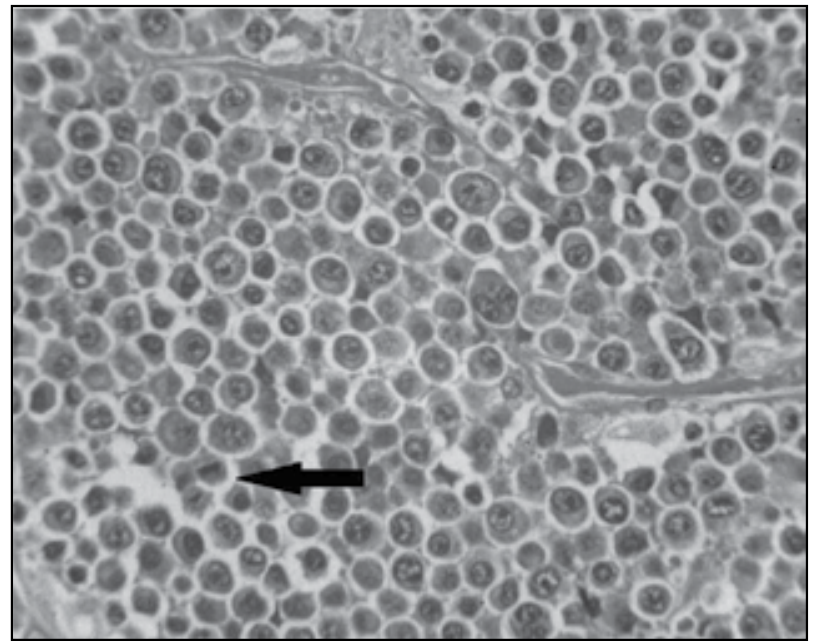

Figure 2 - A malignant neoplasm composed of plasmacytoid cells showing high mitotic index, $H E$, 400x

$H E$ : hematoxylin and eosin.

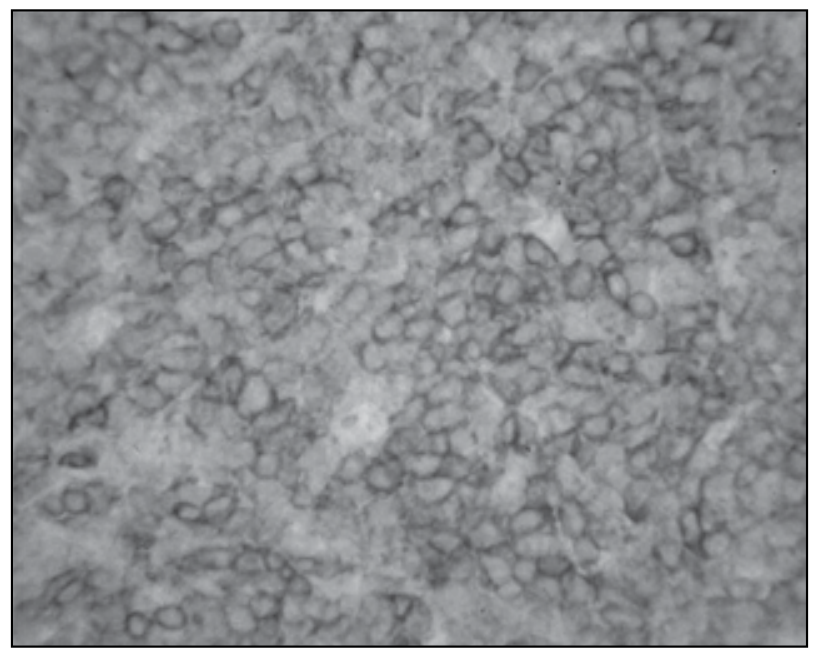

Figure 3 - Plasmacytoid cells showed positive immunoexpression for CD138, streptavidin-biotin, 100x

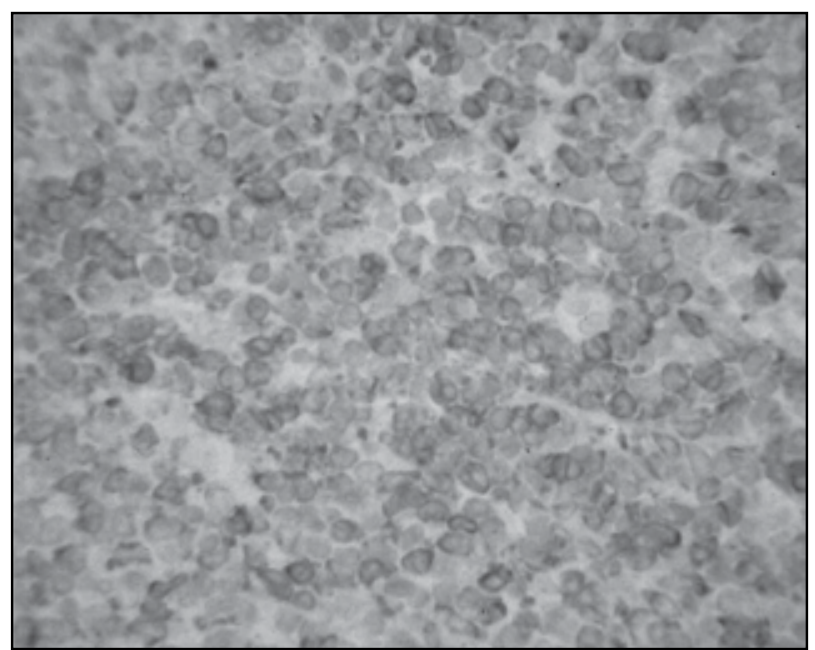

Figure 4 - Plasmacytoid cells showed positive immunoexpression for kappa light chains of immunoglobulins, streptavidin-biotin, 100x

\begin{tabular}{|c|c|}
\hline $\begin{array}{l}|l| \\
\text { Table }\end{array}$ Primary plasmacytoma of the thyroid gland: \\
\hline clinical data \\
\hline T3 & $73 \mathrm{ng} / \mathrm{dl}$ \\
\hline Red blood cells & $0.99 \mathrm{ng} / \mathrm{dl}$ \\
\hline Hemoglobin & $5.05 \mathrm{mill}$ lions/ul \\
\hline Hematocrit & $14.2 \mathrm{~g} / \mathrm{dl}$ \\
\hline Leukocytes & $40.4 \%$ \\
\hline Urea & $7.110 / \mathrm{ul}$ \\
\hline Creatinine & $28 \mathrm{mg} / \mathrm{dl}$ \\
\hline Sodium & $1,03 \mathrm{mg} / \mathrm{dl}$ \\
\hline Potassium & $138 \mathrm{mEg} / \mathrm{l}$ \\
\hline Glicemia & $4.2 \mathrm{mEq} / \mathrm{l}$ \\
\hline Beta-2-microglobulin & $105 \mathrm{mg} / \mathrm{dl}$ \\
\hline C reactive protein & $2.4 \mathrm{mg} / \mathrm{l}$ \\
\hline IgM & $25.9 \mathrm{mg} / \mathrm{l}$ \\
\hline IgG & $22.5 \mathrm{mg} / \mathrm{dl}$ \\
\hline IgE & $514 \mathrm{mg} / \mathrm{dl}$ \\
\hline IgA & $5.1 \mathrm{Ul} / \mathrm{ml}$ \\
\hline Myelogram & $39 \mathrm{mg} / \mathrm{dl}$ \\
\hline Alpha-1 globulin & Normoblastic normocelular \\
\hline Alpha-2 globulin & $6.4 \%-0.32 \mathrm{~g} / \mathrm{dl}$ \\
\hline Beta globulin & $11.9 \%-0.60 \mathrm{~g} / \mathrm{dl}$ \\
\hline Gama globulin & $9.8 \%-0.5 \mathrm{~g} / \mathrm{dl}$ \\
\hline Total proteins & $9.9 \%-0.5 \mathrm{~g} / \mathrm{dl}$ \\
\hline Albumin & $5.07 \mathrm{~g} / \mathrm{dl}$ \\
\hline
\end{tabular}

T3: triiodothyronine; T4: thyroxine; IgM: immunoglobulin class $M$; IgG: immunoglobulin class G; IgE: immunoglobulin E; IgA: immunoglobulin $A$.

neoplasm of bone. The disease spans a spectrum from localized, indolent lesion, to aggressive, disseminated forms with plasma cell infiltration of various organs. Solitary plasmacytoma comprises a minor percentual of the plasma cell neoplasms, and it is characterized by a clonal proliferation of plasma cells that are cytologically and immunophenotypically identical to those of multiple myeloma, but it arises as a single localized osseous lesion. Solitary plasmacytoma of bone affects more frequently the vertebrae, ribs, skull, pelvis, femur, clavicle, and scapula $(2,6,8,9)$.

Extraosseous (extramedullary) plasmacytoma are uncommon plasma cell neoplasms, that arise typically in adults with a median age of 55 years, and approximately $80 \%$ of the cases occur in the upper respiratory tract including the 
oropharynx, sinuses and larynx. They may occur also in the gastrointestinal tract, urinary bladder, central nervous system, breast, testis, parotid gland, lymph nodes, and skin. Thyroid primary plasmacytoma are extremely rare tumors. By definition, there is no evidence of plasma cell myeloma on bone marrow examination or by radiography. $15 \%-20 \%$ of patients may have a monoclonal gammopathy. There is no evidence of anaemia, hypercalcemia, or renal insufficiency, and Bence-Jones protein is occasionally found in the urine ${ }^{(2,5,6,8,9,15)}$.

On gross evaluation, the thyroid gland compromised by a primary plasmacytoma is enlarged in weight and size. On cut surface, in most cases, the thyroid parenchyma shows a soft gelatinous, fish-flesh, ill-defined solid nodule, or a diffuse, soft gray process. The size of the tumor ranges from a few centimeters in diameter to large tumoral masses, which can involve the extrathyroidal tissues too. Occasionally, the lesion shows areas of necrosis and hemorrhage. On histopathological evaluation, the neoplastic plasma cells vary from mature forms to immature, anaplastic cells. In the mature form, the plasma cells are usually oval, with a round eccentric nucleus with a "spoke wheel" chromatin without nucleoli, with abundant basophilic cytoplasm and a marked perinuclear hof. In immature forms, the cells have dispersed nuclear chromatin, a high nuclear/cytoplasm ra- tio, and prominent nucleoli. Multinucleated, pleomorphic cells can be found. The cytoplasm of the neoplastic plasma cells contains abundant endoplasmic reticulum, which may contain retained, condensed or crystallized cytoplasmic immunoglubulins. On immunohistochemistry evaluation, the neoplastic plasma cells shows positivity for monotypic cytoplasmic immunoglobulin (more commonly immunoglobulin class G [IgG ]), CD38, CD56/58, CD138, kappa/ lambda light chain immunoglubulins, and EMA. Most cases of extraosseous plasmacytoma lack immunoexpression for CD19, CD20, keratin, and chromogranin A. The differential diagnosis includes B-cell lymphomas, MALT lymphomas, medullary carcinoma of the thyroid, and metastatic neoplasms like malignant melanoma ${ }^{(3-5,9-11,13,14,16)}$. The treatment for extraosseous plasmacytoma typically consists of radiation therapy. Regional recurrences develop in approximately $25 \%$ of patients, with the development of typical plasma cell myeloma in about $15 \%$ of the $\operatorname{cases}^{(2,5,9,16)}$.

Herein, the authors described the clinical and pathological findings of a primary plasmacytoma of the thyroid gland. Since the management of extramedullary plasmacytoma is markedly different from the primary thyroid carcinoma, it is fundamental its initial recognition by fine-needle aspiration and clinical analysis of laboratory and imaging data.

\section{References}

1. ADENIRAN, A. J. et al. Correlation between genetic alterations and microscopic features, clinical manifestations, and prognostic characteristics of thyroid papillary carcinomas. Am J Surg Pathol, v. 30, n. 2, p. 216-22, 2006.

2. ALEXIOU, C. et al. Extramedullary plasmacytoma: tumor occurrence and therapeutic concepts. Cancer, v. 85, p. 2305-14, 1999.

3. AVILA, A.; VILLALPANDO, A.; MONTOYA, G.; LUNA, M. A. Clinical features and differential diagnoses of solitary extramedullary plasmacytoma of the thyroid: a case report. Ann Diagn Pathol, v. 13, n. 2, p. 119-23, 2009.

4. BOURTSOS, E. P.; BEDROSSIAN, C. W.; de FRIAS, D. V.; NAYAR, R. Thyroid plasmacytoma mimicking medullary carcinoma: a potential pitfall in aspiration cytology. Diagn Cytopathol, v. 23, n. 5, p. 354-8, 2000.

5. CHAGANTI, S.; GURUNATHAN, R. K.; MCNABOE, E. J. Solitary extramedullary plasmacytoma of the thyroid gland: a case report and review of literature. The Internet Journal of Head and Neck Surgery, v. 2, n. 1, p. 1-4, 2007.
6. DAMAJ, G. etal. Features of extramedullary and extraosseous multiple myeloma: a report of 19 patients from a single center. Eur J Haematol, v. 73, p. 402-6, 2004.

7. DERRINGER, G. A. et al. Malignant Iymphoma of the thyroid: a clinic-pathologic study of 108 cases. Am J Surg Pathol, v. 24, p. 623-39, 2000.

8. DiGIUSEPPE, J. A. Flow cytometric immunophenotyping of plasmacytic neoplasms. Am J Clin Pathol, v. 127, p. 172-84, 2007.

9. GORGAN, T. M.; Van CAMP, B.; KYLE, R. A.; MÜLLERHERMELINK, HARRIS, N. L. In: JAFFE, E. S.; HARRIS, N. L.; STEIN, H.; VARDIMAN, J. W. (Ed.). Plasma cell neoplasms. Tumors of hematopoietic and lymphoid tissue - pathology \& genetics. World Health Organization Classification of Tumours. Lyon: IARC Press, 2001, p. 142-56.

10. KABA, S. et al. Cytologic findings of primary thyroid MALT lymphoma with extreme plasma cell differentiation: FNA cytology of two cases. Diagn Cytopathol, v. 37, n. 11, p. 815-9 2009. 
11. KUO, S. F.; CHANG, H. Y.; HSUEH, C.; LIN, J. D. Extramedullary plasmacytoma of the thyroid. N Z Med J, v. 119, n. 1235, p. U2005, 2006.

12. MERCANTE, G. et al. Prognostic factors affecting neck lymph node recurrence and distant metastasis in papillary microcarcinoma of the thyroid: results of a study in 445 patients. Thyroid, v. 19, n. 7, p. 707-16, 2009.

13. OHSHIMA, M. et al. Primary plasmacytoma of the thyroid: a case report and comparative literature study between Western nations and Japan. Pathol Int, v. 44, n. 8, p. 645-51, 1994.
14. PARK, B. J.; KALISH, R. J.; VERCILLO, A. P. Disseminated plasmacytoma of the thyroid. Ear Nose Throat J, v. 89, n. 3, p. 137-9, 2010.

15. SEREFHANOGLU, S. et al. Extramedullary plasmacytomas of the thyroid and pericardium as initial presentation of multiple myeloma. Ann Hematol, v. 87, n. 10, p. 8534, 2008.

16. TERRIER, B. et al. Thyroid gland plasmacytoma with a dramatic and persistent complete response under thalidomide and dexamethasone-associated treatment. Lek Lymphoma, v. 47, n. 7, p. 1424-6, 2006. 